\title{
ODDZIAŁYWANIE HELLENIZMU NA JUDAIZM
}

Zjawisko oddziaływania kultury greckiej na judaizm jest powszechnie znane. Nie trzeba tego udowadniać. Warto się jednak zastanowić nad tym, w jaki sposób to oddziaływanie się rozwijało, w miarę rozwoju kultury greckiej i w miarę rozwoju judaizmu. W niniejszym artykule większa uwaga będzie zwrócona na kulturę grecką, w której z kolei podkreślona zostanie jej etap historyczny zwany hellenizmem. Termin helleńskość określa wcześniejszy etap kultury rodzimej, nieskażonej, klasycznej, natomiast termin hellenizm oznacza mieszankę kulturową, która występowała zarówno w Grecji, jak i poza jej granicami. Hellenizm był owocem spotkania kultury greckiej z wieloma kulturami krajów ogarniętych podbojami Aleksandra Macedońskiego.

Zagadnienie oddziaływania hellenizmu na judaizm generuje szereg pytań: Czy teksty biblijne przetłumaczone na język grecki zawierają w sobie Boże Objawienie? Czy teksty napisane w języku greckim były kontynuacją objawienia, rozpoczętego w środowisku hebrajskim? Czy grecki język i sposób myślenia zostały wybrane przez Boga, by lepiej wyrazić myśli, które chciał ludziom przekazać, czy raczej było odwrotnie, ludzie samowolnie tworzyli swoje komentarze, odbiegające od zamysłu Bożego? Czy w tekstach biblijnych można odróżnić wpływ helleńskości, czyli rodzimej kultury Greckiej, od wpływu hellenizmu, czyli mieszanki kulturowej? Jeżeli tak, to wcześniejsze pytania trzeba odnosić osobno do jednego i do drugiego nurtu kulturowego, nie tyle do języka, co raczej do dwóch 
różnych sposobów greckiego myślenia. Jeżeli judaizm może się wyrażać w języku greckim, to zarówno w mentalności helleńskiej, czy również w kategoriach hellenizmu? Można postawić hipotezę, że helleńskość sprzyjała kontynuacji Objawienia i pogłębiała jego rozumienie, natomiast hellenizm nie stanowił dobrego podłoża dla wyrażania myśli Bożych, a przy odczytywaniu kanonicznych tekstów był źródłem błędów.

\section{1. ŚRODOWISKO GEOGRAFICZNE JUDAIZMU HELLENIST YCZNEGO}

Spotkanie judaizmu z hellenizmem dokonało się w wielkich ośrodkach kulturowo-geograficznych, w Palestynie, Antiochii i Aleksandrii.

\subsection{Palestyna}

Oddziaływanie hellenizmu na judaizm to tylko fragment o wiele szerszego i głębszego zjawiska, jakim jest oddziaływanie różnych kultur na judaizm. Mówienie o takim oddziaływaniu ma sens wtedy, gdy kultura żydowska jest już dojrzała, skonkretyzowana. Hellenizm jest mieszanką kultury greckiej wyrazistej, znajdującej się na bardzo wysokim stopniu rozwoju, z innymi kulturami, również odpowiednio rozwiniętymi. Kultura żydowska byłaby jedną z wielu. Podobnie też działo się z judaizmem.

W Palestynie oddziaływanie ze wschodu było bezpośrednie i dlatego bardzo mocne, natomiast oddziaływanie kultury greckiej nie było tak silne jak w diasporze znajdującej się na zachód od Palestyny. Można by się zastanawiać nad tym, czy istnieją jakieś aspekty wspólne pomiędzy bezpośrednim oddziaływaniem kultur Mezopotamii na judaizm i oddziaływaniem okrężnym, poprzez Grecję. Hellenizm to mieszanka kultury greckiej i kultur wschodnich. Oznacza to, że przez Grecję przenikały do judaizmu elementy kultur wschodnich, a przez kraje ościenne na wschodzie przenikały elementy kultury greckiej. Czy oddziaływanie myśli i wierzeń na judaizm było takie 
samo z jednej i drugiej strony? Czy można rozstrzygnąć precyzyjnie, na ile wpływ na księgi pisane przez Żydów miała rodzima kultura grecka, a na ile kultury wschodnie?

Wiadomo, że po niewoli Babilońskiej monoteistyczna wiara Izraela trzeszczała pod naporem synkretyzmu. Kolejne etapy rozwoju literatury judaistycznej oznaczały kolejne etapy oddziaływania na nią kultury hellenistycznej. Oddziaływanie kultur ościennych, zwłaszcza z terenu Mezopotamii, stanowiło zagrożenie wobec najważniejszej kwestii, wobec monoteizmu. Wpływ hellenizmu na judaizm dotyczył sposobu wyrażania myśli, polegał nie tylko na racjonalizowaniu myślenia, ale miał znaczenie o wiele szersze, systemowe. Racjonalizacja była cechą typową dla kultury Greckiej. Mogłaby służyć jako narzędzie dla bogatszego wyrażania Objawienia. Zagrożeniem nie było precyzyjne myślenie, lecz zawarta w nim treść, stanowiąca kulturową mieszankę, która przyszła do Grecji ze Wschodu. Była to taka sama treść, jaka wdzierała się w myślenie Ludu Bożego bezpośrednio z imperium Babilońskiego. Judaizm przejmował z Grecji idee hellenistyczne, panteistyczne, przeciwne monoteizmowi, np. platońska „dusza świata” albo stoickie „prawo uniwersalne”. Większe zagrożenie tworzył hellenizm dla Żydów w diasporze, którzy przyjęli grecki sposób rozumowania. Argumenty rozumowe przekonywały bardziej niż odczuwanie emocji związanych z kultem, czy też odczucia mistyczne. Żydzi palestyńscy, bardziej tradycyjni, którzy nie byli zarażeni racjonalizmem, byli bardziej odporni na hellenizm. Spotkanie z hellenizmem mogło być dla judaizmu pożyteczne. Wśród Żydów pojawiły się trzy postawy wobec hellenizmu. Jedni podjęli dialog inni weszli w polemikę, inni odrzucali wszystko, co obce. Istniały też nurty wyraźnego i całkowitego sprzeciwu, zachowujące nieskażoną profetyczną spuściznę narodu Izraelskiego - Hasidim. Tworzyli oni zalążek żydowskiej apokaliptyki i początek ruchu faryzeuszy².

1 Por. R. Trevijano Et cheverría, Orígenes del cristianismo. Transfondo judio del cristianismo primitivo, Ed. Publicaciones Universidad Pontificia Salamanca, Salamanca 1995, s. 61.

2 Por. Tamże, s. 62. 
Hellenizm najpierw pojawił się w diasporze. W ,judaizmie późnym" dotarł do Palestyny. Najważniejsze kwestie poruszane w tak okrzepłym już judaizmie hellenistycznym to: królestwo mesjanistyczne, zmartwychwstanie zmarłych, sąd ostateczny i świat przyszły. Wierzono, że każdy człowiek będzie osądzony tuż po śmierci, otrzymując od razu nagrodę lub karę. Zmartwychwstanie dotyczy tylko sprawiedliwych, niesprawiedliwi znikną. Tak rozumiana eschatologia późnego judaizmu była kształtowana przez hellenistyczną koncepcję duszy oraz przez klasyczny grecki sposób myślenia filozoficznego, podkreślający wymiar indywidualny. Oba elementy antropologiczne wpłynęły na ukształtowanie się poglądu o stanie pośrednim, w którym człowiek sprawiedliwy oczekuje na przyszłe zmartwychwstanie. Saduceusze odrzucali greckie innowacje na temat życia przyszłego. Pozostawali oni przy starej, hebrajskiej koncepcji śmierci i szeolu, ale niektórzy głosili pogląd, że po śmierci wszyscy ludzie przestają istnieć 3 .

W literaturze międzytestamentalnej pojawiło się ponadto przeświadczenie o bliskim końcu świata. Pod wpływem hellenizmu, w tradycji palestyńskiej, coraz silniej podkreślano dualizm między doczesnością i życiem przyszłym. Nie było natomiast dążenia do systematyzacji i tworzenia całościowego systemu eschatologii żydowskiej, ubogaconej pomysłami rodem z hellenizmu. Była tylko mozaika różnych poglądów ${ }^{4}$.

\subsection{Diaspora}

Diaspora żydowska kształtowała się przez wieki poprzedzające przyjście Chrystusa. Wielka wspólnota postała w niewoli babilońskiej. W nowej erze - Chrystusowej - po katastrofach, które spotkały Naród Wybrany w latach 70 i 135, gdy brakło świątyni, faryzeusze zdołali zjednoczyć wyznawców judaizmu wokół Prawa i ich własnej

3 Por. S. Z a ñ a r t u, El concepto de Z $\Omega$ H en Ignacio de Antioqia, Publicaciones de la Universidád Pontificia Comillas, Ed. Eapsa, Madrid 1977, s. 66.

4 Por. Tamże, s. 67. 
tradycji. Duchowym centrum judaizmu stali się rabini z Jamni w roku 70 i rabini z Galilei w roku 1355. Po upadku Babilonii wygnańcy mogli wrócić do ojczyzny, jednak wielu z nich pozostało w Mezopotamii z przyczyn ekonomicznych. Przez kilka wieków Żydzi osiedlali się też w Egipcie ${ }^{6}$. Obszar diaspory żydowskiej, tworzonej po niewoli Babilońskiej, w większości pokrywał się ze sferą wpływów hellenizmu. Hellenizacja dotyczyła jednak tylko sfery zewnętrznej. Pomimo tego, że Żydzi przebywali w różnych środowiskach kulturowych, zachowali swoją religię i wyznaczony przez nią ład społeczny.

Typowym przykładem nieskażonego zachowania wiary w sytuacji nowego środowiska kulturowego były prowadzone przez Żydów badania biblijne w Museionie, w egipskiej Aleksandrii. Komentowali oni Biblię, wykorzystując metody, które Grecy stosowali do badania tekstów Homera. W badaniach tych wyróżniali się: Arystobul (II wiek przed Chrystusem) oraz Filon (zm. ok. 45 r. po Chrystusie) 7 . Najwyraźniejszym przykładem egzegety żydowskiego, myślącego kategoriami greckimi jest Filon Aleksandryjski. Nie chciał on odchodzić od tradycji hebrajskiej, wręcz odwrotnie, jego zamiarem było pogodzenie dwóch różnych kultur, hebrajskiej i greckiej. Interesujące jest to, czy czerpał jedynie z klasycznej filozofii greckiej, czy też środowisko greckie spowodowało, że uległ również innym kulturom, zawartym w mieszance, zwanej hellenizmem ${ }^{8}$.

Diaspora żydowska w Aleksandrii wzrastała w sprzyjających warunkach, ponieważ pluralizm kulturowy hellenizmu realizowany był też w wymiarze społecznym. W pierwszych wiekach panowania hellenistycznego w Egipcie mogli się osiedlać przedstawiciele różnych ludów. Jednoczyli się oni i zamykali w swoich własnych społecznościach, tworząc odrębne dzielnice (politéuma). Tak uczynili Żydzi

5 Por. R. Trevija no Etcheverría, Orígenes del cristianismo..., dz. cyt., s. 89 .

${ }^{6}$ Por. Tamże, s. 91.

7 Zob. S. W i e lg u s, Badania nad Biblia w starożytności i w średniowieczu, TNKUL, Lublin 1990, s. 31.

8 Por. P. A r gá r a t e, El hombre creado a la imagen y semajanza de Dios en San Máximo el Confesor, „Communio”, 30 (1997) f. 2-3, 189-219, s. 194. 
w Aleksandrii. Podobnie było w innych miastach w Egipcie. W początkach chrześcijaństwa myśl żydowsko-aleksandryjska, łącząca judaizm z hellenizmem, była wysoko rozwinięta. Jej rozkwit nastąpił wskutek tego, że zarówno chrześcijanie Żydzi, jak i chrześcijanie Grecy, przyjmowali zrozumiałe dla jednych i dla drugich, kategorie myślenia żydowsko-aleksandryjskie. Tymczasem rabini palestyńscy okopywali się w dawnej tradycji hebrajskiej, bronili się przed hellenizmem, byli nieufni wobec Żydów ulegających hellenizmowi ${ }^{9}$.

\section{SFERA JEZZYKA}

Dziedziną, w której ewidentnie język grecki wszedł w kulturę judaistyczną, był język. Można się zastanawiać nad tym, czy tylko sam język, czy również sposób myślenia? Czy język grecki był tylko szatą, narzędziem dla wyrażania myśli typowo hebrajskich? Czy raczej wraz z terminologią przejęta została również treść greckich słów? Do tego dochodzi kwestia poprawności przekładu. Nie zawsze $\mathrm{w}$ drugim języku istnieje słowo adekwatne do oryginału, a nawet wtedy gdy tak jest, tłumacz mógł zastosować słowo zupełnie inne, nieodpowiednie, zawierające inną treść. Bywa, że w przekładzie pojawia się zafałszowanie z powodu braku rozumienia. Może się też okazać, że w obcym języku jakaś kwestia jest wyjaśniona lepiej niż w języku źródłowym. Na ogół jednak tłumaczenie powiązane jest z ryzykiem popełnienia błędów, a także z możliwością wejścia w zupełnie inny sposób myślenia.

\subsection{Przekład Pisma Świętego z hebrajskiego na grecki}

Objawienie dokonało się w środowisku judaistycznym i hellenistycznym. Myśl judaistyczna podkreśla wymiar czasowy, historyczny,

9 Por. R. Trevija no Etchever ría, Orígenes del cristianismo..., dz. cyt., s. 93. 
myśl grecka podkreśla przestrzenność ${ }^{10}$. Język hebrajski jest plastyczny, zdolny do wyrażania dynamizmu i zmienności. Język grecki skierowany jest na abstrakcje, idee, statyczne schematy. Judaizm hellenistyczny wahał się między tymi dwoma ujęciami i próbował je łączyć. Widoczne jest to w księgach pisanych bezpośrednio po grecku i w komentarzach tworzonych przez Żydów hellenistów ${ }^{11}$.

Pod wpływem platonizmu i neoplatonizmu w Aleksandrii popularna była metoda alegoryczna (Filon z Aleksandrii, a następnie wielu myślicieli chrześcijańskich). Komentarze czynione w liturgii, czy podczas celebrowania wydarzeń społecznych były dopasowywane do sytuacji. Egzegeza literalna ustępowała egzegecie alegorycznej, duchowej, moralnej. W takiej sytuacji trudno odróżnić specyfikę hebrajską i grecką. Wszystko wskazuje na to, że hellenizm spowodował, że żydowskie komentarze były bardziej swobodne „rozwijając z czasem tzw. midrasz, tj. prawniczy wykład tekstu (halach), np. o szabacie, oraz wyjaśnianie budująco-moralne (haggada)"12. W kulturze hellenistycznej można odróżnić nurt filozoficzny-klasyczny, oraz nurt poetycko-religijny, powstały wskutek pomieszania z innymi kulturami. Podobnie żydowskie komentarze do Pisma Świętego można podzielić ma dwie grupy, w zależności od tego, jaki nurt hellenistyczny oddziaływał na ich autorów.

W niektórych dziełach hellenistycznych Żydzi spotykali oryginalną myśl hebrajską, w innych napotykali na judaizm zmieszany $z$ hellenizmem. $Z$ tego względu niektórzy badacze dowodzili, że filozofa grecka była inspirowana przez Mojżeszową myśl, którą zawiera Tora, która jest źródłem filozofii najwyższej i najbardziej prawdziwej. W takim ujęciu, oddziaływanie kultury greckiej na judaizm byłoby powracającą falą, niosącą coś oryginalnie greckiego, ale też coś, co

${ }^{10}$ Por. P. L i s z k a, Wptyw nauki o czasie na refleksję teologiczna, Palabra, Warszawa 1992, s. 7.

11 Por. B. S e s b o ü é, Pierwsze dyskursy chrześcijańskie i tradycje wiary, w: B. S e s b o ü é (red.) Historia Dogmatów, T. 1, B. S e s b o ü é, J. W o 1 i ń s k i, Bóg Zbawienia. Tradycja, reguła i Symbole wiary. Ekonomia zbawienia. Rozwój dogmatów trynitarnych i chrystologicznych, (tłum. P. Rak), Kraków1999, 21-61, s. 55.

12 Cz. S. B a r t n i k, Dogmatyka Katolicka, t. 1, Lublin 2000, s. 275. 
należy do kultury hebrajskiej i powracając nie zniekształca judaizmu, lecz go umacnia ${ }^{13}$. Pojawiło się też przekonanie, że skoro już raz Mojżesz znalazł uznanie u Greków, to ich potomkowie też będą dobrze nastawieni wobec religii żydowskiej. W tym nurcie 4 Księga Machabejska kierowała się ku środowisku kultury hellenistycznej, starając się opisywać religię żydowską jako prawdziwą filozofię ${ }^{14}$.

Wyraźnie hellenizm wpłynął na Księgę Mądrości, zwłaszcza na jej antropologię. Odzwierciedlone tam są poglądy szkoły aleksandryjskiej, czyli poglądy środowiska greko-hellenistycznego. Według tej księgi, dusza ludzka została stworzona nieśmiertelna, na podobieństwo nieśmiertelności Boga (Mdr 2,23) ${ }^{15}$. Pod wpływem hellenistycznego sposobu myślenia Księga Mądrości mówi też o poznaniu Boga na podstawie analogii istniejącej między nim a stworzeniem $\left(\right.$ Mdr 13, 5) ${ }^{16}$. Wyraźny aspekt hellenistyczny ma Księga Barucha, zachowana jedynie w przekładzie greckim została przejęta przez chrześcijan. Tradycja żydowska aleksandryjska zaliczała je do cyklu Jeremiasza z Lamentacjami oraz Listem Jeremiasza ${ }^{17}$. Hellenizacja Starego Testamentu dokonała się poprzez przekłady ksiąg pisanych w języku hebrajskim, a następnie poprzez pisanie nowych ksiąg w języku greckim, w środowisku kultury greckiej. Księgi mądrościowe, przepojone były już myśleniem hellenistycznym. W otoczce hellenistycznej przekazywana była jednak treść, znajdująca się na przeciwnym wobec hellenizmu biegunie. Bogiem nie jest wszechświat, lecz Jahwe, Stwórca świata, który jest jednocześnie Stwórcą historii indywidualnej i społecznej człowieka: auctor historiae. Jahwe

13 Por. R. Trevija no Et chever ría, Origenes del cristianismos..., dz. cyt., s. 133.

14 Por. Tamże, s. 134.

15 Por. P. A rgá r a t e, El hombre..., dz. cyt., s. 192.

16 Por. B. M i k o ł a j c z a k, Analogia III. W Teologii, A. Dzieje, w: Encyklopedia Katolicka, t. 1, Lublin 1989, kol. 498-504, kol. 498.

17 Zob. L. S t a c how i a k, Barucha Księga, w: Encyklopedia katolicka, t. II, Lublin 1985, 90-91, s. 90. 
jest również podmiotem nadającym społeczności ludzkiej prawa etyczne i socjalne ${ }^{18}$.

Odrzucenie z Objawienia wszystkiego tego, co greckie, oznacza nie tylko odrzucenie Nowego Testamentu, lecz również ksiąg pisanych poza nim. Judaizm rabinistyczny ustalił, że kanonem żydowskim jest tylko Pięcioksiag. Inne księgi są deutero-kanoniczne, czcigodne, ale nie święte. Mimo to, synagoga hellenistyczna uważała za święte wiele Ksiąg zawartych w Septuagincie. W diasporze thumaczenia ustne z hebrajskiego na grecki były coraz bardziej okazyjne i częściowe. Zanikała znajomość języka hebrajskiego. $\mathrm{Z}$ tego powodu pojawiło się niebezpieczeństwo, że Słowo Boże całkowicie zamilknie. Tłumaczenie Tory na język grecki było konieczne ${ }^{19}$. Septuaginta otworzyła poganom drogę do poznania mądrości Izraela. Grecy hellenistyczni przyjmowali obce wartości chętnie i z łatwością. Poszukiwali oni prawdy w swojej tradycji, a także w innych kulturach. Grecka wersja Biblii hebrajskiej otworzyła przed nimi perspektywy nowe, dotąd nieznane. Septuaginta stała się też wehikułem prozelityzmu ${ }^{20}$. R. T. Etchevarría mówi o potrójnym wpływie na religijność hellenistyczną. Po pierwsze, na hellenizm oddziaływała siła monoteizmu semickiego. Po drugie, judaizm mógł być interpretowany uniwersalistycznie i w tej postaci mógł być wsparciem dla uniwersalistycznie nastawionego hellenizmu. Po trzecie, hellenizm przemieniał się, nieświadomie, w Preparatio Ewangelica dla chrześcijaństwa ${ }^{21}$.

Hellenizacja judaizmu stała się okazją do wzbogacenia hellenizmu o nową kulturę, która zdecydowanie wyróżniała się spośród wszystkich innych kultur. Wszystkie kultury, znane dotąd, były z łatwością asymilowane przez Greków. Wspólnym mianownikiem było nastawienie panteistyczne. Jedynie judaizm był zdecydowanie inny, anty-panteistyczny, gdzie Bóg był transcendentny wobec świata. Judaizm

\footnotetext{
18 Por. Cz. S. B a r t n i k, Dogmatyka..., dz. cyt., s. 269.

19 Por. R. Trevija no Etcheve r ría, Orígenes del cristianismo..., dz. cyt., s. 125 .

20 Por. Tamże, s. 126.

21 Por. Tamże, s. 127.
} 
pomógł wrócić kulturze greckiej do swojej wcześniejszej formy, pomógł przemienić myślenie panteistyczne na myślenie integralne.

\subsection{Zmiany w kulturze żydowskiej pod wpływem hellenizmu}

Hellenizacja judaizmu dokonała się nie tylko w sferze języka. Ogarniała całość życia społecznego. Istniało też oddziaływanie o przeciwnym zwrocie. Zhellenizowany judaizm wpływał na świat języka greckiego, przyczyniając się do powstania wielu nowych pojęć i konceptów. Oddziaływanie w obie strony widoczne jest już, jak w ognisku soczewki, w języku Septuaginty, należącym do kilku epok i kultur. Często bywa tak, że jakieś słowo greckie odpowiadało wielu słowom hebrajskim, i odwrotnie, słowo hebrajskie mogło być tłumaczone na kilka sposobów, za pomocą kilku słów greckich. Poprzez Septuagintę, judaizm hellenistyczny wpływał nie tylko na język grecki, ale też na sposób myślenia, a w efekcie na całość życia społecznego. Hellenizm zmienił rozumienie Boga oraz Bożej Opatrzności. Szczególnie na pojęcie Opatrzności w literaturze mądrościowej Starego Testamentu miał wpływ stoicyzm. Opatrzność (pronoia) stoicy stawiali na równi z fatum (heimarmené). Z tego powodu nie potrafili oni zespolić Opatrzności z ludzką wolnością ${ }^{22}$.

Nie było asymilacji judaizmu z hellenizmem. Grecy i Rzymianie nadal byli wrogo nastawieni wobec Żydów, i odwrotnie. Rabini obawiali się wymieszania żydowskiego monoteizmu z greckim politeizmem lub panteizmem. Dlatego odrzucali ze swej tradycji wszystko, co miało jakikolwiek związek z hellenizmem. Walczyli między innymi ze wspólnotą w Qumran, a później, już radykalnie, z chrześcijaństwem. Nie zrozumieli oni Objawienia rozwijanego przez Boga. Prawdziwym powodem walki z wieloma nurtami judaizmu był fakt,

${ }^{22}$ Por. P. B o l b e r i t z, Opatrzność jako współcierpienie Boga, „Communio”, 6 (2002) 46-59, s. 52. 
że zapowiadały Mesjasza. Wynikało z nich, że chrześcijaństwo jest oczywistym spełnieniem Starego Testamentu ${ }^{23}$.

Hellenizm oddziaływał na judaizm raczej tylko zewnętrznie. Nie wpływał na przekonania religijne. Nie spowodowała duchowych szkód, nie zrujnował żydowskiej kultury. Wręcz odwrotnie, wzmocnił samoświadomość, pozwolił zrozumieć Objawienie w szerszym kontekście kulturowym i społecznym, a w końcu pomógł szczy towe osiągnięcie judaizmu, którym było chrześcijaństwo, wprowadzić nie tylko do Grecji, ale do całego hellenistycznego uniwersum.

\section{CHARAKTERYSTYKA JUDAIZMU HELLENISTYCZNEGO}

Hellenizacja judaizmu spowodowała pojawienie się nowego sposobu myślenia oraz wprowadziła szereg nowych tematów.

\subsection{Sposób myślenia judaizmu hellenistycznego}

Nurt rabinacki przeciwstawiał się hellenizmowi, ale wiele z niego korzystał. Pozytywnym skutkiem tego oddziaływania było ożywienie myślenia racjonalnego, podjęcie starań zmierzających ku systematyzacji Objawienia oraz większe zainteresowanie kosmologią i antropologią. Wiele wieków dziejów Izraela przyniosło wymieszanie różnorodnych nurtów ideologicznych. Przeciwnicy hellenizmu bronili się przez chaosem, ale odnajdywali w myśli greckiej tendencje zmierzające do porządkowania i tworzenia spójnych systemów filozoficznych. W judaizmie pojawiła się analogiczna tendencja, jeszcze bardziej dalekosiężna. Ujawniły się dążenia do spójnego ujęcia nadprzyrodzonej mądrości z tradycyjną pobożnością, oraz

23 Por. V. C o 11 a d o B e r t o m e u, Qumran y el cristianismo, w: Cristianismo y culturas. Problemática de inculturación del mensaje cristiano, Actas del VIII simposio de teología histórica, Facultad de teología San Vicente Ferrer, Series Valentina XXXVII, Valencia 1995, 215-222, s. 218. 
krytycznych tendencji uniwersalistycznych z troską o zachowanie wierności dziedzictwu proroków ${ }^{24}$.

Spotkanie judaizmu z hellenizmem rozciągnęło się na tysiąclecia. Obrona przed hellenizmem spowodowała, że przez całe pierwsze tysiąclecie po Chrystusie, myśl żydowska narodowa utożsamiana była z myśla boska. Później hellenizm zatriumfował. Około X wieku pojawiała się w judaizmie typowa dla hellenizmu myśl filozoficzna lub naukowa ${ }^{25}$. Hellenizm przeszedł do judaizmu drogą okrężną, z Zachodu, poprzez kulturę arabską. Ujawnił się w ,czterech postaciach myśli żydowskiej: religijnej, mistycznej, filozoficznej i naukowej”26. Dzieła greckie docierały do Europy w większości od strony zachodniej, przez Hiszpanię, okupowaną przez muzułmanów. Judaizm włączył się w nurt hellenizmu i stał się przekaźnikiem wiedzy od starożytnej Grecki do chrześcijan, w środowisku islamskim. Trwało oddziaływanie hellenizmu na judaizm, ale też trwało oddziaływanie judaizmu na hellenistyczne działa przekazywane z jego pośrednictwem do religii chrześcijańskiej.

Przekłady z arabskiego lub hebrajskiego na łacinę naznaczone były już islamskim lub żydowskim myśleniem religijnym. Myśl grecka przekształcana była przez myślicieli arabskich i żydowskich. Wzmacniała się w ten sposób najważniejsza cecha hellenizmu. Tworzona była coraz bardziej zawiła mieszanka kulturowa. Wywodzące się ze środowiska żydowskiego chrześcijaństwo, zetknęło się z hellenizmem już na początku. Tysiąc lat później sytuacja się powtórzyła. Chodziło nie tylko o zetknięcie się z kulturą grecką, lecz ze znacznie bardziej złożoną kulturową mieszanką ${ }^{27}$.

Od czasów Aleksandra Macedońskiego w judaizmie istnieją dwa zasadnicze nurty: rabinacki i hellenistyczny. Widoczne są one przez

${ }^{24}$ R. Trevijano Etcheverría, Orígenes del cristianismo..., dz. cyt., S. 88 .

${ }_{25}$ Por. J. O c h m a n, Średniowieczna filozofia żydowska, (Historia filozofii żydowskiej, t. 2), Universitas, Kraków 1995, s. 5.

${ }^{26}$ Por. Tamże, s. 6.

${ }^{27}$ Por. G. L a fo n t, Storia teologica della Chiesa. Itinerario e forme della teologia, Edicioni San Paolo, Torino 1997, s. 127. 
wszystkie wieku, aż do dziś. Typowym przykładem nurtu rabinackiego jest dzieło Nefesh Hahayyim, którego autorem jest Gaon z Wilna, Hayyim de Volozhyn (zm. 1821). E. Lévinas uważa to dzieło za potężną syntezę egzegetyczną pism biblijnych, talmudycznych i kabalistycznych. Jego zamiarem było oczyszczenie judaizmu z konceptów filozofii greckiej i z myślenia mitycznego. Sposób myślenia wileńskiego rabina był bliski stoicyzmowi. Sądził on, że uwolnienie religii od mitów sprawia, że religia stanie się bardziej etyką. Hermeneutyka przez niego stosowana zwalczała wszelkie interpretacje mistyczne biblijnych obrazów i wprowadzała w ich miejsce interpretacje etyczne ${ }^{28}$. Lévinas kontynuował ten kierunek myślenia w XX wieku. Podobieństwa widoczne są nie tylko w podejmowanych tematach, lecz przede wszystkim w stylu myślenia, wynikającym z podobnego środowiska społecznego i religijnego. Obu myślicieli żydowskich różni inne nastawienie do hellenizmu. Hayyim de Volozhyn bardziej skłaniał się ku nurtowi rabinackiemu. Lévinas natomiast chciał przetłumaczyć nie-helleńskie wątki biblijne w terminach helleńskich ${ }^{29}$. Hellenizacja judaizmu trwa do dziś.

Dialektycznie holistyczne myślenie hellenistyczne z integralnym myśleniem żydowskim łączył też kontynuator linii Levinasa, André Neher. Starożytne myślenie żydowskie wiązało wydarzenia historyczne z refleksją intelektualną. Język wydarzeń przekładany był na język mówiony i pisany. Historia ukazywana była nie tylko w aspekcie materialnym, lecz również w całej sferze duchowej, w której znaczącą rolę odkrywa ludzkie myślenie. Judaizm łączy ,ż̇ycie” (czyli działanie materialne) z teorią (czyli myśleniem). Życie człowieka, w odróżnieniu od zwierząt, to przede wszystkim myślenie. Historia nie jest zbiorem dziejów odizolowanych od siebie jednostek, lecz ich wzajemną ciągłą komunikacją, przekazywaniem rzeczy, słów, myśli, wartości duchowych, w sposób przestrzenny i czasowy. Hellenizm

28 Por. M. L. C o s t a, Emmanuel Lévinas y Hayyim de Volozhyn: praximidad e inspiración, „Anámnesis” (Meksyk), 1 (1998) 129-145, s. 132.

${ }_{29}$ Por. Tamże, s. 133; Zob. E. L é v i n a s, De Dieu qui vient à l'idée, París 1982, s. 142. 
pomógł myśli judaistycznej widzieć dzieje ludzkości syntetycznie, ujmować w spójny system ${ }^{30}$.

\subsection{Treść myśli judeo-hellenistycznej}

Problem relacji między judaizmem a hellenizmem polega na spotkaniu się myślenia mieszającego $\mathrm{z}$ myśleniem oddzielającym. Judaizm nie potrafił dostrzec różnicy między elementem duchowym i materialnym w człowieku. Hellenizm nie potrafił dostrzec człowieka jako psycho-fizycznej jedności. Według rabinów, Pierwsze Przymierze interpretuje człowieka nie wychodząc od jego natury, lecz od jego relacji z Bogiem. Bóg jest mocą, człowiek ciałem-słabym. Dualizm kreacjonistyczny został poszerzony na ludzką naturę: człowiek jest boski poprzez swoją duszę i ziemski poprzez swoje ciało-korpus ${ }^{31}$.

Hellenizm wpłynął na antropologię Starego Testamentu. Księga Daniela zamiast o sercu, symbolizującym w kulturze hebrajskiej ośrodek myślenia, mówi o umyśle (Dn 4, 7; 7, 1-15). W antropologii greckiej było coś, co nie miało odpowiedników hebrajskich. W sferze duchowej to coś określane jest polskim terminem $d u s z a^{32}$. Nie wiadomo, czy słowo to oznacza duchowy budulec, duchową energię, czy tylko schemat, formę, strukturę elementu materialnego. To samo dotyczy greckiego słowa psyche. W tekstach polskich stosowane jest dla określenia wielu różnych rzeczywistości ${ }^{33}$. Literatura biblijna starotestamentalna pisana w języku greckim nadaje słowom greckim znaczenie hebrajskie. „W kanonicznych księgach ST czy w LXX

${ }^{30}$ Por. M. R. C a p e 11 i n i, André Neher e l'ermeneutica biblica, "Studia Patavina", 46 (1999) nr 1, 109-141, s. 110.

31 Por. A. Rodríg u z C a r mon a, El hombre en el judaismo, „Estudios Biblicos”, 57 (1999) 589-611, s. 597.

32 Zob. P. L i s z k a, Korzenie hebrajskie rozumienia duszy ludzkiej - nefesz, „Życie konsekrowane”, 4 (102) 2013, s. 56-69.

33 Zob. Tenże, Interpretacja terminu „psyche” w Piśmie Świętym i w teologii, „Teologia w Polsce”, nowa seria, 7 (2013) nr 2, s. 45-61. 
słowo psyche ma zasadniczo treść hebrajskiego nefesz, ale niekiedy występuje jako podmiot zmartwychwstania (2 Mch 7, 9; 7, 14. 23)"34.

W kontekście helleńskiego uniwersalizmu pojawia się idea apokatastazy. Czy wynika ona z Miłosierdzia Bożego, o którym można mówić nie tylko w chrześcijaństwie, ale też w ramach judaizmu, czy raczej wynika z hellenistycznego panteizmu? Biblia hebrajska mówi na temat sądu ostatecznego, wyeliminowania zła, ograniczonego zakresu zbawienia. Myśl helleńska jest uniwersalistyczna, otwarta na wszystko, nawet na pogodzenie dobra ze złem. Mówiąc o wpływie hellenizmu ha judaizm trzeba brać pod uwagę nie tylko starożytną myśl grecką, ale też kultury wchodzące w skład uniwersalnej mieszanki. W każdym razie w ślad za antropologią, terenem badań nad kwestią oddziaływania hellenizmu na judaizm powinna być również eschatologia ${ }^{35}$.

Centralne miejsce w teologii zajmuje refleksja nad Misterium Boga. W tym względzie, zagadnieniem, w którym widoczny jest wpływ hellenizmu na judaizm, jest monarchia Boga. Termin monarchia był powszechnie znany i jednoznacznie rozumiany w starożytnej, rodzimej kulturze helleńskiej i w późniejszej mieszance kulturowej, zwanej hellenizmem. W środowiskach judaizmu hellenistycznego termin monarchia Boża miał dwa ogniska tematyczne: monoteizm i działanie Boga w stworzeniach ${ }^{36}$. Termin monarchia, stosowany był przez Filona z Aleksandrii dla mówienia o jedyności Boga. Posługiwał się on wersami Iliady (II, 204), które wiązał z tekstami Genesis (Rdz 1, 26; 3, 22) ${ }^{37}$. Filon był pierwszym, który mówiąc o biblijnych opisach stworzenia, zastosował terminologię

${ }^{34}$ L. S t a c how i a k, Antropologia biblijna. A. Stary Testament i środowisko judaistyczne, w: Encyklopedia Katolicka, t. 1, Lublin 1985, kol. 689-692, kol. 691.

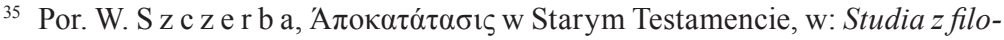
zoficznej tradycji chrześcijaństwa, w: M. M a n i k o w s k i (red.), Filozofia XXVIII, Wydawnictwo Uniwersytetu Wrocławskiego, Wrocław 1998, 13-40, s. 36.

36 Por. G. Uríbarri Bil b a o, Monarquia y Trinidad, Publicaciones de la Universidad Pontificia Comillas. Madrid, serie I: Estudios 62. wyd. UPCO (Universidad Pontificia Comillias), Madrid 1996, s. 58.

37 Por. Tamże, s. 58. 
filozoficzną. W ten sposób przeniósł akcent z mówienia o Bogu na mówienie o kosmosie ${ }^{38}$.

Dzięki hellenizacji judaizmu wiele zagadnień zostało ukazanych bardziej głęboko i bardziej wyraźnie. Również całość treści wiary była ukazywana w sposób bardziej spójny i przekonujący. Kultura helleńska pozwoliła docierać religii żydowskiej na cały znany ówcześnie świat.

\section{Streszczenie}

Hellenizacja judaizmu jest zjawiskiem, które pojawiło się wraz z nastaniem hellenizmu. Hellenizm określony został jako wynik oddziaływania wielu kultur, zwłaszcza azjatyckich, na rodzimą kulturę grecką, helleńską. Kontakt między Grecją a wieloma kulturami istniał już wcześniej. Podobnie istniał kontakt Izraela z wieloma kulturami. Nasilenie oddziaływania nastąpiło w czasach niewoli Babilońskiej. Dla Grecji całkowicie nowy etap rozpoczęły wyprawy Aleksandra Macedońskiego. Wcześniej kontakt Narodu Wybranego z grecką filozofią i mitologią był nieznaczny. Od IV wieku przed Chrystusem oddziaływanie kultury greckiej na judaizm ogarnęło wszelkie dziedziny życia. Nikły strumyk przemienił się w potop. Jednocześnie zmieniło się natężenie oddziaływania i jego jakość. Przyczyna jednego i drugiego była ta sama. Początek zależności politycznej narodu Izraelskiego od Grecji zbiegł się z początkiem przemiany helleńskości w hellenizm.

Wpływ hellenizmu na judaizm był wieloraki, ale w istotnej dziedzinie, $w$ wierze, niczego nie zmienił. Przekład Biblii na język grecki, pisanie ksiąg biblijnych w języku greckim, mówienie w tym języku i życie w środowisku tworzonym przez Greków, nie zmieniło biblijnego sposobu myślenia i nie zniekształciło objawionej treści.

Judaizm nie miał większego wpływu na kulturę grecką. Kultura żydowska została przyjęta przez Greków dopiero wraz z percepcją chrześcijaństwa.

38 Por. Tamże, s. 62. 


\section{Impact of Hellenism on Judaism Summary}

Hellenization of Judaism occurred at the inception of Hellenism. Hellenism has been described as a result of the influence of many cultures, in particular Asiatic cultures, on Greek, Hellenic culture. Greece had come into contact with other cultures even earlier. Likewise, Israel had come into contact with other cultures earlier. That influence reached its pinnacle during the Babylonian Captivity. In the case of Greece it were the conquests by Alexander the Great that initiated a new stage in the development. Prior to this, the contact of the nation of Israel with Greek philosophy and mythology was negligent. Since the $4^{\text {th }} \mathrm{BC}$ the influence of Greek culture on Judaism has encompassed all spheres of life. An initial slight stream burst its banks and turned into a flood. At the same time the intensity and the quality of the said influence underwent changes. Both stemmed from the same cause. The beginning of Israeli national independence of Greece coincided with the beginning of the change of Hellenic culture into Hellenism.

The impact of Hellenism on Judaism was manifold; it has not changed anything of great import in the faith, though. The translation of the Bible into Greek, the writing of the biblical books in Greek, use of Greek as a language of communication did not change the biblical way of thinking and did not warp the revealed message.

Judaism did not have much impact on Greek culture. Hebrew culture was only accommodated by Greeks with the adoption of Christianity.

\section{Bibliografia:}

Argárate P., El hombre creado a la imagen y semajanza de Dios en San Máximo el Confesor, „Communio”, 30(1997) f. 2-3, 189-219, s. 194.

Bartnik Cz. S., Dogmatyka Katolicka, t. 1, Lublin 2000.

Bolberitz P., Opatrzność jako współcierpienie Boga, „Communio”, 6(2002) nr 4659, s. 52.

Capellini M.R., André Neher e l'ermeneutica biblica, "Studia Patavina", 46(1999) nr 1, 109-141, s. 110.

Collado Bertomeu V., Qumran y el cristianismo, w: Cristianismo y culturas. Problemática de inculturación del mensaje cristiano, Actas del VIII simposio de teología histórica, Facultad de teología San Vicente Ferrer, Series Valentina XXXVII, Valencia 1995, 215-222, s. 218. 
Costa M.L., Emmanuel Lévinas y Hayyim de Volozhyn: praximidad e inspiración, „Anámnesis” (Meksyk), 1(1998) 129-145, s. 132.

Lafont G., Storia teologica della Chiesa. Itinerario e forme della teologia, Edicioni San Paolo, Torino 1997.

Lévinas E., De Dieu qui vient à l’idée, París 1982.

Liszka P., Interpretacja terminu ,psyche” w Piśmie Świętym i w teologii, „Teologia w Polsce", nowa seria, 7(2013) nr 2, s. 45-61.

Liszka P., Korzenie hebrajskie rozumienia duszy ludzkiej-nefesz, „Życie konsekrowane", 4(102) 2013, s. 56-69.

Liszka P., Wpływ nauki o czasie na refleksję teologiczna, Warszawa 1992.

Mikołajczak B., Analogia III. W Teologii, A. Dzieje, w: Encyklopedia Katolicka, t. 1, Lublin 1989, kol. 498-504, kol. 498.

Ochman J., Średniowieczna filozofia żydowska, (Historia filozofii żydowskiej, t. 2), Kraków 1995.

Rodríguez Carmona A., El hombre en el judaismo, „Estudios Biblicos”, 57(1999) 589-611, s. 597.

Sesboüé B., Pierwsze dyskursy chrześcijańskie i tradycje wiary, w: B. Sesboüé (red.) Historia Dogmatów, t. 1, B. Sesboüé, J. Woliński, Bóg Zbawienia. Tradycja, reguła i Symbole wiary. Ekonomia zbawienia. Rozwój dogmatów trynitarnych i chrystologicznych, (tłum. P. Rak), Kraków1999, 21-61, s. 55.

Stachowiak L., Antropologia biblijna. A. Stary Testament i środowisko judaistyczne, w: Encyklopedia Katolicka, t. 1, Lublin 1985, kol. 689-692, kol. 691.

Stachowiak L., Barucha Księga, w: Encyklopedia katolicka, t. II, Lublin 1985, 90-91, s. 90.

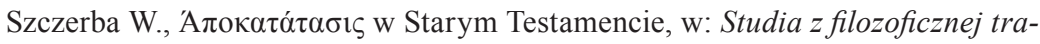
dycji chrześcijaństwa, w: M. Manikowski (red.), Filozofia XXVIII, Wrocław 1998, 13-40, s. 36.

Trevijano Etcheverría R., Orígenes del cristianismo. Transfondo judio del cristianismo primitivo, Ed. Publicaciones Universidad Pontificia Salamanca, Salamanca 1995.

Uríbarri Bilbao G., Monarquia y Trinidad, Publicaciones de la Universidad Pontificia Comillas. Madrid, serie I: Estudios 62. wyd. UPCO (Universidad Pontificia Comillias), Madrid 1996, s. 58.

Wielgus S., Badania nad Biblią w starożytności i w średniowieczu, Lublin 1990.

Zañartu S., El concepto de Z $\Omega \mathrm{H}$ en Ignacio de Antioqia, Publicaciones de la Universidád Pontificia Comillas, Ed. Eapsa, Madrid 1977. 